\title{
Red Blood cell distribution width: an emerging diagnostic factor of acute appendicitis?
}

\author{
Ergenekon Karagöz ${ }^{1 *}$ and Alpaslan Tanoglu²
}

\begin{abstract}
Acute appendicitis is the most common surgical abdominal emergency. Immidiate diagnosis of this disease is crucial, because this condition can lead to appendiceal perforation, potential peritonitis, and even death. We read with great interest the article The role of red cell distribution width (RDW) in the diagnosis of acute appendicitis: a retrospective case-controlled study' by Narci et al. and wanted to discuss whether RDW alone provide certain information about the inflammatory status of the patient with acute appendicitis.
\end{abstract}

\section{Dear editor}

We read with great interest the article "The role of red cell distribution width in the diagnosis of acute appendicitis: a retrospective case-controlled study' by Narci et al. [1]. They aimed to evaluate whether red cell distribution width (RDW) has a role in the diagnosis of acute appendicitis. The authors concluded that if compared to healthy controls, RDW levels were lower in patients with acute appendicitis. Being inexpensive and easy attainability of this parameter may strengthen its utilization in daily practice in the near future. We would like to thank the authors for their contribution.

RDW which is used in the differential diagnosis of anemia, is an automated measure of the variability of red blood cell size [2]. Previously it was shown that, RDW is an independent variable of prognosis in patients with cardiovascular diseases such as heart failure, myocardial infarction, strokes, and pulmonary hypertension [2-6]. In addition, it was also found to be related to mortality and other severe adverse outcomes in renal and infectious diseases [7]. Aging, malnutrition, Iron or vitamin B12 deficiency, bone marrow depression, or chronic inflammation may affect RDW levels [1,2]. Thus, it would have been better, if the authors had mentioned these RDW affecting factors.

In a previous study, two novel biomarkers, calprotectin (CP) and serum amyloid A (SAA) were found to be related to acute appendicitis [8]. Recent studies have demonstrated

\footnotetext{
* Correspondence: ergenekonkaragoz@hotmail.com

'Department of Infectious Diseases and Clinical Microbiology, GATA

Haydarpasa Training Hospital, 34668, Uskudar, Istanbul, Turkey

Full list of author information is available at the end of the article
}

that Neutrophil-to-Lymphocyte Ratio and mean platelet volume (MPV) are also associated with inflammatory diseases $[9,10]$. In this view, it would also be relevant, if the authors included these parameters in the study.

We are of the opinion that the findings of Narci et al. [1] will lead to further research concerning the relationship between RDW and acute appendicitis. Nevertheless, RDW should be considered with other inflammatory markers (e.g. C-reactive protein, procalcitonin, calprotectin) to provide certain information about the inflammatory status of the patient.

\section{Competing interests}

We have no competing interests to declare.

\section{Author details}

'Department of Infectious Diseases and Clinical Microbiology, GATA Haydarpasa Training Hospital, 34668, Uskudar, Istanbul, Turkey. ${ }^{2}$ Department of Internal Medicine, Gastroenterology, GATA Haydarpasa Training Hospital, Istanbul, Turkey.

Received: 10 December 2013 Accepted: 19 December 2013 Published: 26 December 2013

\section{References}

1. Narci H, Turk E, Karagulle E, Togan T, Karabulut K: The role of red cell distribution width in the diagnosis of acute appendicitis: a retrospective case-controlled study. World J Emerg Surg 2013, 8:46 [Epub ahead of print].

2. Lou Y, Wang M, Mao W: Clinical usefulness of measuring red blood cell distribution width in patients with Hepatitis B. PLoS One 2012, 7(5): e37644. doi: 10.1371/journal.pone.0037644. Epub 2012 May 23.

3. Allen LA, Felker GM, Mehra MR, Chiong JR, Dunlap SH, Ghali JK, Lenihan DJ, Oren RM, Wagoner LE, Schwartz TA, Adams KF Jr: Validation and potential mechanisms of red cell distribution width as a prognostic marker in heart failure. J Card Fail 2010, 16:230-238.

4. Dabbah S, Hammerman H, Markiewicz W, Aronson D: Relation between red cell distribution width and clinical outcomes after acute myocardial infarction. Am J Cardiol 2010, 105:312-317. 
5. Ani C, Ovbiagele B: Elevated red blood cell distribution width predicts mortality in persons with known stroke. J Neurol Sci 2009, 277:103-108.

6. Hampole CV, Mehrotra AK, Thenappan T, Gomberg, Maitland M, et al: Usefulness of red cell distribution width as a prognostic marker in pulmonary hypertension. Am J Cardiol 2009, 104:868-872.

7. Chen B, Ye B, Zhang J, Ying L, Chen Y, RDW to Platelet Ratio: A novel noninvasive index for predicting hepatic fibrosis and cirrhosis in chronic hepatitis. B. PLoS One 2013, 8(7):e68780. doi: 10.1371/journal.pone.0068780. Print 2013.

8. Schellekens DH, Hulsewé KW, van Acker BA, van Bijnen AA, de Jaegere TM, Sastrowijoto SH, Buurman WA, Derikx JP: Evaluation of the diagnostic accuracy of plasma markers for early diagnosis in patients suspected for acute appendicitis. Acad Emerg Med. 2013, 20:703-710.

9. Ekiz O, Balta I, Sen BB, Rifaioglu EN, Ergin C, Balta S, Demirkol S: Mean platelet volume in recurrent Aphthous Stomatitis and Behçet Disease. Angiology 2013: . Jun 13 [Epub ahead of print].

10. Fu SJ, Shen SL, Li SQ, Hua YP, Hu WJ, Liang LJ: Prognostic value of preoperative peripheral neutrophil-to-lymphocyte ratio in patients with HBV-associated hepatocellular carcinoma after radical hepatectomy. Med Oncol 2013, 30:721.

doi:10.1186/1749-7922-8-54

Cite this article as: Karagöz and Tanoglu: Red Blood cell distribution width: an emerging diagnostic factor of acute appendicitis? World Journal of Emergency Surgery 2013 8:54.

\section{Submit your next manuscript to BioMed Central and take full advantage of:}

- Convenient online submission

- Thorough peer review

- No space constraints or color figure charges

- Immediate publication on acceptance

- Inclusion in PubMed, CAS, Scopus and Google Scholar

- Research which is freely available for redistribution 